\title{
Effects of mannan oligosaccharides and fructooligosaccharides on the growth and nonspecific immune responses of juvenile freshwater prawn Macrobrachium acanthurus
}

\author{
Yazmín Varela-Granados ${ }^{1}(\mathbb{D})$, Susana Alejandra Frías-Gómez ${ }^{1} \mathbb{D}^{\mathbb{D}}$, Luis Héctor Hernández-Hernández ${ }^{1}$ \\ Madison S. Powell $^{2} \mathbb{D}$ \& Fernando Vega-Villasante ${ }^{3}[\mathbb{C}$ \\ ${ }^{1}$ Laboratorio de Producción Acuícola, Facultad de Estudios Superiores Iztacala \\ Universidad Nacional Autónoma de México, Tlalnepantla, México \\ ${ }^{2}$ Aquaculture Research Institute, University of Idaho, Hagerman, Idaho, US A \\ ${ }^{3}$ Laboratorio de Calidad de Agua y Acuicultura Experimental, Centro de Investigaciones Costeras \\ Universidad de Guadalajara, Jalisco, México \\ Corresponding author: Luis Héctor Hernández-Hernández (luish3@yahoo.com)
}

\begin{abstract}
The freshwater prawn Macrobrachium acanthurus represents a valuable resource for fishermen's communities in Mexico, although the information of its culture conditions and nutrition is still scarce. Prebiotics are defined as non-digestible components that are metabolized by specific health-promoting bacteria in the host's digestive system, improving the health status and growth performance of cultured aquatic organisms. Fructooligosaccharides (FOS) and mannan oligosaccharides (MOS) are among the most used prebiotics in aquaculture. The present work aimed to determine the effects of dietary FOS and MOS in the growth performance, immune responses, and sexual maturity of juvenile freshwater prawn Macrobrachium acanthurus. Juveniles $(0.06 \pm 0.001 \mathrm{~g})$ were fed with diets supplemented with a $3 \mathrm{~g} \mathrm{~kg}^{-1}$ diet of commercial FOS and MOS for 80 days. At the end of the feeding trial, the following indices were calculated: weight gain, specific growth rate, and feed conversion efficiency, as well as superoxide dismutase and lysozyme activities in hepatopancreas tissue. The growth performance, survival, juveniles' protein contents did no show significant differences among the groups. No differences were detected in superoxide dismutase and lysozyme activities among experimental groups. Around day 60 of the feeding trial, the females fed with the prebiotics maturated, and by the end of the trial, several of them were carrying eggs. It seems that prebiotics might have a role in sexual maturation, but further research is necessary to establish if prebiotics influences the early maturation of $M$. acanthurus.
\end{abstract}

Keywords: Macrobrachium acanthurus; growth; lysozyme; prebiotics; sexual maturation; superoxide dismutase

\section{INTRODUCTION}

The freshwater prawn Macrobrachium acanthurus Wigmann 1836 is distributed along the American continent's east coast, from North Carolina, USA, and down to the Rio Grande do Sul, Brazil (GarcíaGuerrero et al. 2013). In Mexico, this species represents a valuable resource for fishermen's communities in the states of Veracruz and Tabasco (Hernández-Abad et al. 2018). However, in recent years natural populations have been declining due to several problems related to overfishing, water pollution, and destruction of their natural ecosystems (Kutty \& Valenti 2010). According to Kutty \& Valenti (2010) and Yamasaki-Granados et al. (2012), this species' culture is an alternative to fisheries, as it might help decrease pressure on wild populations and provide employment for local fishers. Although the information on the culture conditions of M. acanthurus is still scarce (Kutty \& Valenti 2010), several reports regarding their nutrient requirements are available (Hernández et al. 2015, Villafuerte et al. 2016, Hernández-Abad et al. 2018). Prebiotics are defined as non-digestible components that are metabolized by specific health-promoting bacteria in the host's digestive system (Ring $\varnothing$ et al. 2010). These compounds have been reported to improve health status (Dawood 
\& Koshio 2016) and aquatic organisms' growth performance (Munir et al. 2016). Fructooligosaccharides (FOS) and mannan oligosaccharides (MOS) are among the most used prebiotics in aquaculture. The FOS is short and medium chains of $\beta$ - - -fructans, units bound together by $\beta-(2-1)$ glycosidic linkages and attached to a terminal glucose unit (Ring $\varnothing$ et al. 2010). The MOS is glucomannoproteins derived from the yeast's cell wall, Saccharomyces cerevisiae (Gainza \& Romero 2017). $\mathrm{Li}$ et al. (2007) reported that several FOS concentrations in the white shrimp diet (Penaeus vannamei) did not affect growth performance, but gut microbiota was affected. Zhou et al. (2007) reported that supplementations of FOS between 0.4 and $0.16 \%$ significantly improved specific growth rate and feed conversion of white shrimp and affected gut microbiota composition. Red swamp crayfish (Procambarus clarkii) showed enhanced immune response in a dosedepend way when FOS was included (Dong \& Wang 2013). The inclusion of $0.4 \%$ FOS improved growth performance, short-chain fatty acid production, and hepatopancreas condition of the giant freshwater prawn (Macrobrachium rosenbergii) post-larvae (Chen et al. 2017). Additionally, Genc et al. (2007) reported that MOS included at $3 \mathrm{~g} \mathrm{~kg}^{-1}$ improved the growth and survival of the shrimp Penaeus semisulcatus. Van Hain \& Fotedar (2009) found that Penaeus latisulcatus showed higher growth, survival, immune response, and changes in intestinal morphology when fed MOS 0.5\%. Similarly, Sang et al. (2011) found that MOS at $0.4 \%$ improved growth performance and the freshwater crayfish Cherax destructor's immunological condition. The inclusion of 1-2 $\mathrm{g} \mathrm{kg}^{-1}$ of MOS improved growth performance and the physiological and immunological condition of black tiger prawn, Penaeus monodon (Sang et al. 2014). Safari et al. (2014) reported that a diet containing a combination of $2.25 \mathrm{~g} \mathrm{~kg}^{-1}$ of MOS and $1.5 \mathrm{~g} \mathrm{~kg}^{-1}$ of FOS enhanced the growth performance of juvenile narrow clawed crayfish Astacus leptodactylus leptodactylus, along with immune responses against air and bacterial exposure challenges. Therefore, the present work aimed to determine the effects of dietary FOS and MOS in the growth performance and lysozyme and superoxide dismutase activities on the hepatopancreas of juvenile freshwater prawn Macrobrachium acanthurus.

\section{MATERIALS AND METHODS}

\section{Experimental organisms}

Juvenile Macrobrachium acanthurus were obtained from the Jamapa River, Municipality of Boca del Río, Veracruz, Mexico $\left(19^{\circ} 02^{\prime} \mathrm{N}, 96^{\circ} 14^{\prime} \mathrm{W}\right)$. The prawns were collected with a spoon net and then packed in a plastic bag for their transportation to the Laboratorio de Producción Acuícola of FES Iztacala-UNAM. Once in the laboratory, the juveniles were stocked in $200 \mathrm{~L}$ glass tanks equipped with continuous filtration and aeration, and the temperature was regulated with thermostats at $30^{\circ} \mathrm{C}$. The juveniles were fed a diet $(40 \%$ crude protein, $15 \%$ crude lipids) for an acclimation period of two weeks before the feeding trial was started.

\section{Diet formulation}

A basal diet was formulated with fishmeal (Vimifos S.A. de CV, Sonora, México) and krill meal (AkerBioMarine AS, Oslo, Norway) as protein sources to provide inclusion of $40 \%$ crude protein (Villafuerte et al. 2016). The basal diet was added, either with fructooligosaccharides (FOS, FortiFeed P-95, Ingredion México S.A. de C.V., México) or mannan oligosaccharides (MOS, ActiveMOS, Ferpac Internacional S.A. de C.V., México) at $3 \mathrm{~g} \mathrm{~kg}^{-1} \operatorname{diet}$ (minimum inclusion, according to with the manufacturer's instructions) to the basal diet and produce the diet FOS and the diet MOS, respectively (Table 1). As a control, the basal diet was used. Besides the protein sources, cod liver oil (Drotasa, S.A. de C.V., México), soybean lecithin (Drotasa, S.A. de C.V., México), and cholesterol (94\%, Sigma-Aldrich Co., St. Louis, MO, USA) were used as lipid sources, while dextrin (SigmaAldrich Co., St. Louis, MO, USA) was used a carbohydrate source. Vitamin and mineral mixtures were added according to Teshima et al. (2006). Wheat gluten was used as a binder. The diets were prepared according to Villafuerte et al. (2016) by mixing all the powered ingredients for $20 \mathrm{~min}$, then the fish oil, cholesterol, and soybean lecithin were added and remixed for another $20 \mathrm{~min}$. Water $(40 \% \mathrm{v} / \mathrm{w})$ was added to produce a wet dough and passed through a meat mincer, and produce pellets of $5 \mathrm{~mm}$ in diameter. The pellets were dried at $60^{\circ} \mathrm{C}$ for $6 \mathrm{~h}$ and kept at $-24^{\circ} \mathrm{C}$ until used.

\section{Feeding trial}

Nine glass tanks of $20 \mathrm{~L}$ were equipped with gravel filters, continuous aeration, and thermostats. Each tank used was a batch type system, with manual water exchanges daily (between 10 and 15\% of the total volume). Six juvenile prawns with an initial weight of $0.06 \pm 0.001 \mathrm{~g}$ (mean \pm standard error) were randomly stocked in each tank. Each diet was fed to triplicate groups of juveniles at $7 \%$ of each tank's total body weight. The daily ration was divided into two equal feedings at 9:00 and 17:00 $\mathrm{h}$. One hour after the feeding, the fecal matter was siphoned from the bottom of each tank. The juveniles were weighed every 10 days, 
Table 1. Formulations of diets with prebiotics fed to juvenile Macrobrachium acanthurus. ${ }^{1} \mathrm{In} \mathrm{mg} 100 \mathrm{~g}^{-1}$ diet: $\rho$-aminobenzoic acid, 15.08; biotin, 0.63; inositol, 632; niacin, 63.2; Ca pantothenate, 94.8; pyridoxine $\mathrm{HCl}, 18.96$; riboflavin, 12.64; thiamine $\mathrm{HCl}, 6.32$; menadione, 6.34; $\beta$-carotene, 15.17; calciferol, 1.90; cyanocobalamin, 0.13; L-ascorbyl-phosphate $\mathrm{Mg}, 55.11$; folic acid, 1.26; choline chloride, 948. ${ }^{2} \mathrm{In} \mathrm{mg} 100 \mathrm{~g}^{-1}$ diet: $\mathrm{K}_{2} \mathrm{HPO}_{4}, 1164 ; \mathrm{Ca}_{3}\left(\mathrm{PO}_{4}\right)_{2}$, 1591; $\mathrm{MgSO}_{4}, 1178.5 ; \mathrm{NaH}_{2} \mathrm{PO}_{4} 2 \mathrm{H}_{2} \mathrm{O}, 461.5$. FOS: Fructooligosaccharides, MOS: mannan oligosaccharides.

\begin{tabular}{lccc}
\hline Ingredient $\left(\mathrm{g} \mathrm{kg}^{-1}\right)$ & Control diet & FOS diet & MOS diet \\
\hline Fishmeal & 300 & 300 & 300 \\
Krill meal & 300 & 300 & 300 \\
Fish oil & 50 & 50 & 50 \\
Soybean lecithin & 50 & 50 & 50 \\
Cholesterol & 10 & 10 & 10 \\
Dextrine & 100 & 100 & 100 \\
Vitamin mix & 20 & 20 & 20 \\
Mineral mix & 20 & 50 & 50 \\
Fructooligosaccharides & 50 & 30 & 0 \\
Mannan oligosaccharides & 0 & 0 & 30 \\
Wheat gluten & 0 & 50 & 50 \\
a-cellulose & 50 & 67 & 67 \\
Proximate composition (\% dry weight basis) & & \\
Crude protein & $40.4 \pm 1.4$ & $39.0 \pm 1.1$ & $40.0 \pm 0.3$ \\
Lipids & $18.8 \pm 1$ & $18.7 \pm 0.5$ & $18.1 \pm 1$ \\
Ash & $13.4 \pm 0.3$ & $12.9 \pm 0.1$ & $12.4 \pm 0.1$ \\
Moisture (\%) & $4.3 \pm 0.2$ & $3.7 \pm 0.2$ & $5.3 \pm 0.3$ \\
\hline
\end{tabular}

and the daily ration was adjusted accordingly. Water quality parameters throughout the feeding trial were (mean \pm standard deviation): dissolved oxygen, $7.1 \pm$ $1.2 \mathrm{mg} \mathrm{L}^{-1} ; \mathrm{pH}, 8.1 \pm 0.05$; temperature, $28.3 \pm 0.8^{\circ} \mathrm{C}$, and ammonia, $0.08 \pm 0.02 \mathrm{mg} \mathrm{L}^{-1}$.

The feeding trial was performed for 80 days, and at the end, the juveniles were starved for $24 \mathrm{~h}$ and then weighed to obtain the growth parameters. Then, the juveniles were euthanized by immersion on ice for 30 min, and samples of the hepatopancreas and muscle were taken to analyze protein content and lysozyme and superoxide dismutase enzyme activities.

\section{Growth performance calculations}

The following parameters were calculated:

Weight gain $\%(\mathrm{WG})=[($ final weight - initial weight $) /$ initial weight] $\times 100$

Specific growth rate $\% \mathrm{~d}^{-1}(\mathrm{SGR})=[(\ln$ final weight ln initial weight) / 80] $\times 100$

Feed conversion efficiency $(\mathrm{FCE})=$ weight gain $(\mathrm{g}) /$ total feed intake dry weight basis $(\mathrm{g})$

Survival rate $(\mathrm{SR})=$ (number of final individuals / numbers of initial individuals) $\times 100$

\section{Chemical analysis}

Diets were analyzed for moisture, ash, and crude protein content according to the AOAC (1990), while lipid content was measured using Blight \& Dyer (1959) technique. Protein content in each juvenile's muscle and hepatopancreas was analyzed using a BCA protein assay kit (23225, Thermo Fisher Scientific, Rockford, IL, USA).

\section{Superoxide dismutase (SOD) activity}

Samples of hepatopancreas were rinsed with phosphate-buffered saline (PSB, Sigma-Aldrich Co., St. Louis, MO, USA) pH 7.4 and then homogenized with $20 \mathrm{mM}$ HEPES buffer (added with EGTA $1 \mathrm{mM}$, mannitol $210 \mathrm{mM}$, and sucrose $70 \mathrm{mM}$ ), pH 7.2 and centrifuged at $10,000 \mathrm{rpm}$ for $5 \mathrm{~min}$ at $4^{\circ} \mathrm{C}$. The supernatant was collected and stored at $-34^{\circ} \mathrm{C}$ until used. The SOD activity was determined with a commercial assay kit (item 706002, Cayman Chemical, MI, USA) with a microplate reader Sunrise (Tecan Group Ltd., Sweden) at $450 \mathrm{~nm}$. One unit (U) of SOD activity is defined as the amount of enzyme to exhibit $50 \%$ dismutation of the superoxide radical. 


\section{Lysozyme activity}

Samples of hepatopancreas were homogenized with PBS and then centrifuged at $10,000 \mathrm{rpm}$ for $10 \mathrm{~min}$, and the supernatant was collected (Aranishi \& Nakane 1997). The activity was determined according to Caruso et al. (2002) using $50 \mu \mathrm{L}$ of the sample added to $150 \mu \mathrm{L}$ of a Micrococcus lysodeikticus aqueous solution $\left(5 \mathrm{mg} \mathrm{mL}^{-1}\right.$ lyophilized cell, Sigma Aldrich Co., St. Louis, MO, USA) to obtain $200 \mu \mathrm{L}$ mix, which was incubated for one hour at $37^{\circ} \mathrm{C}$.

Absorbance was measured at the beginning and the end of the incubation period at $405 \mathrm{~nm}$ with a Sunrise microplate (Tecan Group Ltd., Sweden). One unit (U) of lysozyme is defined as the amount of the enzyme that decreased in absorbance of $0.001 \mathrm{~min} \mathrm{~L}^{-1}$.

\section{Statistical analysis}

Data on growth performance, survival, protein contents in muscle and hepatopancreas, SOD, and lysozyme activities were tested for normality and homoscedasticity with the Shapiro-Wilk test and the Barletts's test, respectively (Zar 1999). All the data showed normality, and homoscedasticity and one-way ANOVA was performed using the Prism v. 8.3.0 software (GraphPad Software, San Diego, CA). As no significant differences were found after the ANOVA test was performed, no post-hoc analysis was done.

\section{RESULTS}

The growth performance of juveniles is shown (Table 2 ). Final weight $(\mathrm{FW})$ and weight gain (WG) did not show significant differences among groups, but higher values were observed in juveniles fed with the control diet. The same trend was observed with the values of specific growth rate (SGR), which was higher in the organism fed the control diet, but no significant differences were observed. Survival rates were similar for all groups (Table 2).

Regarding the protein content of muscle (Fig. 1a), no significant differences were found among the treatments, but lower values were observed in the groups fed the diets with FOS and MOS inclusion. The protein contents in the hepatopancreas (Fig. 1b) did not show significant differences, but lower values were observed again in the organisms fed the MOS and FOS diets.

Superoxide dismutase (SOD) activity in the hepatopancreas is shown in Figure 2, indicating higher activities in the organisms fed the control diet and MOS diet, but significant differences were not observed compared with the FOS diet group.
Figure 3 shows the lysozyme activity in the hepatopancreas, and higher values were observed in the group fed with the MOS diet, but no significant differences were observed compared with the organisms of the other two dietary groups.

Figure 4 shows the total percentage of females, males, egg-bearing females, and individuals who were not identified as male or female (as did not show any characteristic such a long pereopods for males or conspicuous ovaries for females) and denominated as non-defined organisms. At the end of the feeding trial, it was observed that $50 \%$ of the prawns fed the control diet were identified as males, and the other $50 \%$ were non-defined. The organisms fed the diet FOS showed $25 \%$ of the organism as non-defined, $35 \%$ of males, $25 \%$ of females, and $15 \%$ of females carrying eggs. The group fed the MOS diet showed a similar percentage of non-defined organisms as the observed for the FOS diet $(25 \%)$ and $35 \%$ of males, but $40 \%$ of the females carried eggs.

\section{DISCUSSION}

For the first time, the inclusion of a $3 \mathrm{~g} \mathrm{~kg}^{-1}$ diet of fructooligosaccharides and mannan oligosaccharides on the growth and some nonspecific immune responses of juvenile freshwater prawn Macrobrachium acanthurus is reported. Although it was not considered a variable during the study, it was observed that prebiotic inclusion might have a role in the sexual maturation of M. acanthurus.

At the level of inclusion used, the FOS and MOS did not positively affect growth performance compared with the group fed the diet control. It has also been previously reported for Pacific white shrimp (Penaeus vannamei) fed FOS ( $\mathrm{Li}$ et al. 2007) and red swamp crayfish (Procambarus clarkii) fed FOS (Dong \& Wang 2013). However, in other cultured crustaceans (Genc et al. 2007, Zhou et al. 2007, Van Hain \& Fotedar 2009, Sang et al. 2011, 2014, Safari et al. 2014, Chen et al. 2017), the addition of prebiotics has improved growth performance. According to Hoseinifar et al. (2015), prebiotics causes the selective growth of bacteria such as Lactobacillus or Bifidobacterium in the host's gut, and these bacteria may have a positive effect on nutrient digestibility and, thus, with growth. Safari et al. (2014) reported that FOS and MOS used in the diets of juvenile narrow-clawed crayfish (Astacus leptodactylus) improved the growth performance as the supplementation of those compounds increased in the diet. Post-larvae of Macrobrachium rosenbergii showed the highest SGR when fed a supplementation of $0.4 \%$ of FOS (Chen et al. 2017), which might indi- 
Table 2. Growth performance of juvenile Macrobrabrachium acanthurus fed diets with fructooligosaccharides (FOS) and mannan oligosaccharides (MOS). Data are the means of three replicates \pm standard deviation. No significant differences were observed at level $(P<0.05)$. FW: final weight, WG: weight gain, SGR: specific growth rate, FCE: feed conversion efficiency, SR: survival rate.

\begin{tabular}{lccccc}
\hline Treatment & FW $(\mathrm{mg})$ & WG $(\%)$ & SGR $\left(\% \mathrm{~d}^{-1}\right)$ & FCE & SR (\%) \\
\hline Control diet & $1,618 \pm 178$ & $335 \pm 59$ & $1.8 \pm 0.3$ & $0.52 \pm 0.1$ & $66 \pm 16$ \\
FOS diet & $1,605 \pm 108$ & $321 \pm 37$ & $1.7 \pm 0.1$ & $0.49 \pm 0.1$ & $66 \pm 29$ \\
MOS diet & $1,322 \pm 287$ & $257 \pm 74$ & $1.5 \pm 0.2$ & $0.48 \pm 0.1$ & $66 \pm 29$ \\
\hline
\end{tabular}
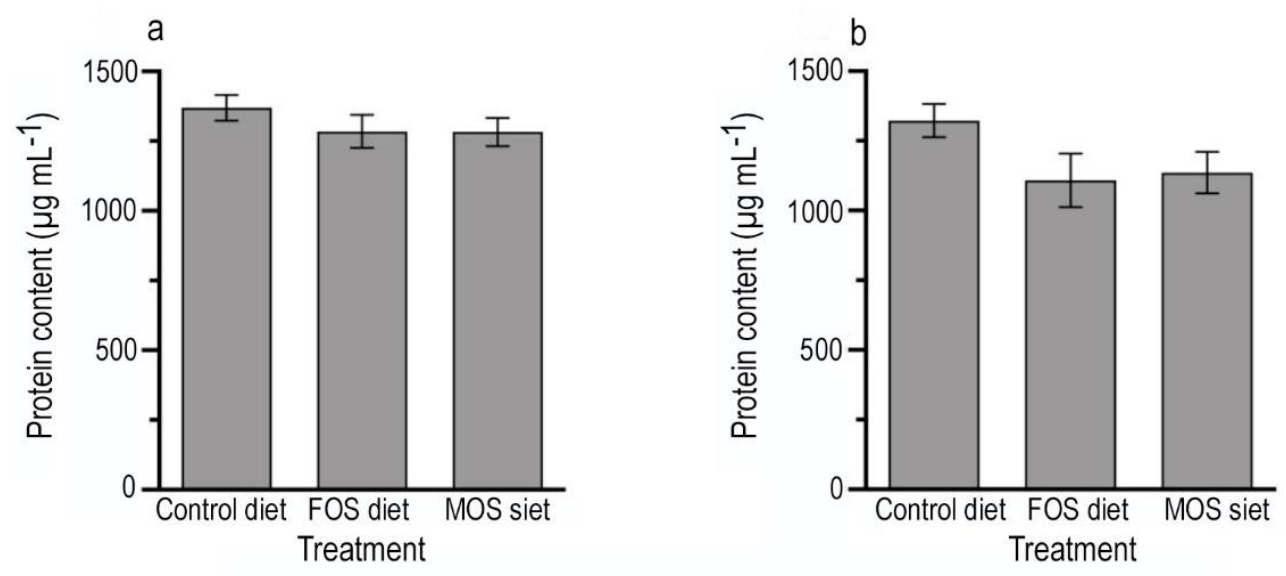

Figure 1. Protein contents of a) muscle and b) hepatopancreas of juvenile Macrobrachium acanthurus fed diets with the inclusion of fructooligosaccharides (FOS) and mannan oligosaccharides (MOS) for 80 days. Each bar represents the mean of three replicates \pm standard deviation. No significant differences were observed at this level $(P>0.05)$.

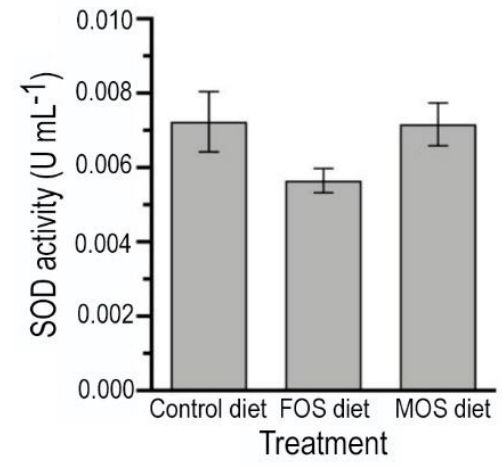

Figure 2. Superoxide dismutase activity in the hepatopancreas of juvenile Macrobrachium acanthurus fed diets with the inclusion of fructooligosaccharides (FOS) and mannan oligosaccharides (MOS) for 80 days. Each bar represents the mean of three replicates \pm standard deviation. No significant differences were observed at this level $(P>$ $0.05)$.

cate FOS and MOS supplementation levels in this experiment were not sufficient to produce higher growth performance in juveniles of $M$. acanthurus. Besides the supplementation level, it was observed that around day 60 of the feeding trial, the females in tanks

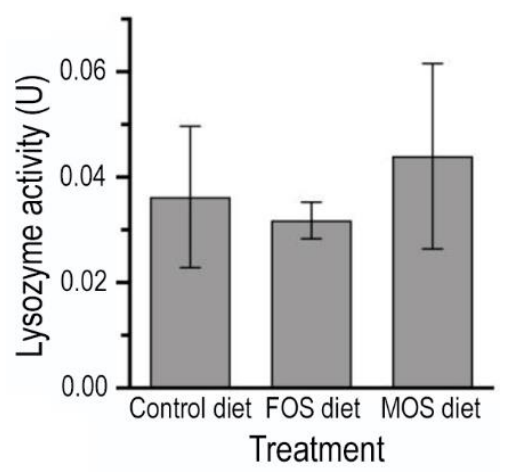

Figure 3. Lysozyme activity in the hepatopancreas of juvenile Macrobrachium acanthurus fed diets with the inclusion of fructooligosaccharides (FOS) and mannan oligosaccharides (MOS) for 80 days. Each bar represents the mean of three replicates SD. No significant differences were observed at this level $(P>0.05)$.

fed with prebiotics started to mature. By the end of the trial, several females were carrying eggs. So, this might be another cause of the non-significant growth performance observed in the $M$. acanthurus juveniles. Maturation and reproduction are highly demanding processes that require energy and nutrients from the 


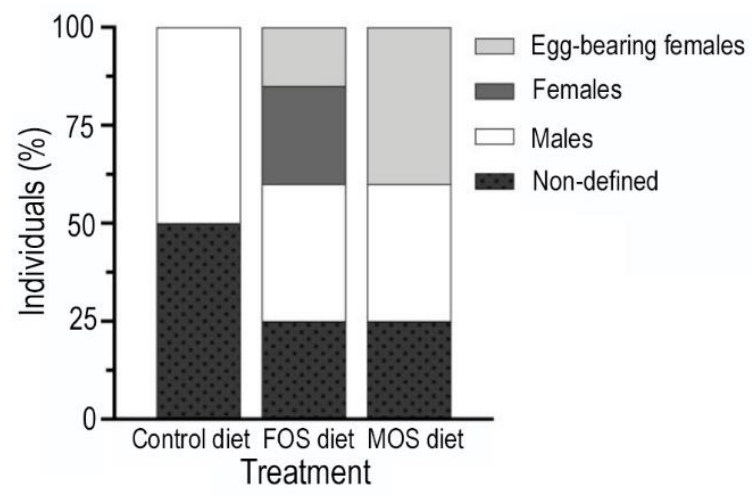

Figure 4. Percentage of females, egg-bearing females, males, and non-defined individuals (individuals with no apparent secondary sexual characters) found at the end of the feeding trial of Macrobrachium acanthurus fed diets with the inclusion of fructooligosaccharides (FOS) and mannan oligosaccharides (MOS) for 80 days.

organisms to develop gonads and produce gametes (NCR 2011). According to Hernandez-Abad et al. (2018), females of $M$. acanthurus (and presumably the males) decreased their growth when they started to mature and produce eggs. This observation might also be confirmed by the contents of protein in the hepatopancreas. Although no significant differences were observed, the protein contents in the prawns' hepatopancreas fed the FOS and MOS supplemented diets were lower than those found in the control group, observed by Hernández-Abad et al. (2018). According to Subramoniam (2011), proteins are mobilized from the hepatopancreas to ovaries to produce vitellogenin. So far, there are no reports of prebiotics' effect on sexual maturation or egg production of decapod crustaceans. Recently Peerakietkhajorn et al. (2019) reported that oligosaccharides derived from the dragon fruit caused Daphnia magna to produce eggs earlier than a control group without adding the oligosaccharides. The prebiotic effect on the sexual maturation and reproduction of crustaceans is worthy of further study.

The use of prebiotics can improve immune responses by allowing bacteria's selective growth (Ring $\varnothing$ et al. 2010). The immune system of crustaceans is often referred to as nonspecific (Rowley 2016) and is the fundamental defense mechanism against infections (Sang et al. 2011). Lysozyme and superoxide dismutase activities are often used as indicators of immune status in crustaceans (Safari et al. 2014).

The SOD catalyzes the dismutation of superoxide anion $\left(\mathrm{O}_{2}^{-}\right)$into hydrogen peroxide and molecular oxygen. This cellular antioxidant defense mechanism plays an important role in crustacean immunity (Dong $\&$ Wang 2013). The inclusion of prebiotics has been shown to improve the SOD activity in the red swamp crayfish (Dong \& Wang 2013) and the narrow-clawed crayfish (Safari et al. 2014). In this study, the SOD activities were not significantly different in the juveniles of $M$. acanthurus fed the prebiotics compared to the control group.

On the other hand, lysozyme is a glycolytic enzyme and a potent antimicrobial protein secreted by crustaceans (Tyagi et al. 2007). According to Rowley (2016), lysozyme is widely distributed within several shrimp and prawn tissues and has activity against Gram-positive bacteria. The hepatopancreas lysozyme activity against Micrococcus lysodeikticus did not show significant differences among groups fed the prebiotics and the control. However, the MOS fed group did have higher lysozyme activities. It has been previously reported that lysozyme activities are higher when MOS is supplemented than those fed FOS in juvenile narrow clawed crayfish (Safari et al. 2014).

The lysozyme and SOD activities improved by prebiotics seems to be dose-dependent, and the inclusion of $3 \mathrm{~g} \mathrm{~kg}^{-1}$ of FOS or MOS for the juvenile $M$. acanthurus might be too low to obtain a positive response. However, as we have described previously, with growth performance, sexual maturation could be affecting lysozyme and SOD activities. Little information about the effects of sexual maturation on immune responses has been published. According to Rohlenová \& Šimková (2010), cyprinids showed a trade-off between immunity and reproduction during sexual maturation, as there is a high investment of energy in gonad development.

In conclusion, $3 \mathrm{~g} \mathrm{~kg}^{-1}$ of the FOS and MOS in the diet of juvenile $M$. acanthurus did not improve growth performance. Lysozyme and SOD activities used as indicators of the immunological status of the organisms were also non-significant. However, it seems that prebiotics might play a role in the sexual maturation of $M$. acanthurus, but further research is necessary to verify this possibility. 


\section{ACKNOWLEDGMENTS}

The economic support from the Consejo Mexiquense de Ciencia y Tecnología del Estado de México (COMECYT) to one of the authors (LHHH) is kindly acknowledge. Thanks are also due to Ingredion Mexico S.A. de C.V. for providing the FOS.

\section{REFERENCES}

Association of Official Analytical Chemists (AOAC). 1990. Official methods of analysis. AOAC, Virginia, pp. 69-78.

Aranishi, F. \& Nakane, M. 1997. Epidermal protease of the Japanese eel. Fish Physiology and Biochemistry, 16: 471-478.

Blight, E.G. \& Dyer, W.J. 1959. A rapid method of total lipids extraction and purification. Canadian Journal of Biochemistry and Physiology, 37: 911-917.

Caruso, D., Schlumberger, O., Dahm, C. \& Proteau, J.P. 2002. Plasma lysozyme levels in the sheatfish Silurian glanis (L.) subjected to stress and experimental infection with Edwarsiella tarda. Aquaculture Research, 33: 999-1008.

Chen, W.W., Romano, N., Ebrahim, M. \& Nathrah, I. 2017. The effects of dietary fructooligosaccharide on growth, intestinal short chain fatty acids level and hepatopancreatic conditions of the giant freshwater prawn (Macrobrachium rosenbergii) post-larvae. Aquaculture, 469: 95-101.

Dawood, M.A.O. \& Koshio, S. 2016. Recent advances in the role of probiotics and prebiotics in carp aquaculture. Aquaculture, 454: 243-251.

Dong, C. \& Wang, J. 2013. Immunostimulatory effects of dietary fructooligosaccharides on red swamp crayfish, Procambarus clarkii (Girard). Aquaculture Research, 44: 1416-1424.

Gainza, O. \& Romero, J. 2017. Mannan oligosaccharides as prebiotics in crustacean aquaculture. Latin American Journal of Aquatic Research, 45: 246-260.

García-Guerrero, M.U., Becerril-Morales, F., VegaVillasante, F. \& Espinosa-Chaurand, L.D. 2013. Los langostinos del género Macrobrachium con importancia económica y pesquera en América Latina: conocimiento actual, rol ecológico y conservación. Latin American Journal of Aquatic Research, 41: 651675.

Genc, M.A., Aktas, M., Genc, M. \& Yilmaz, E. 2007. Effects of dietary mannan oligosaccharides growth, body composition and hepatopancreas histology of Penaeus semisulcatus (de Haan 1844). Aquaculture Nutrition, 13: 156-161.

Hernández-Abad, G.Y., Hernández, L.H.H. \& Fernández, M.A.A. 2018. Effects of different dietary lipids concentrations on the egg production and egg quality produced by Macrobrachium acanthurus females. Latin American Journal of Aquatic Research, 46: 518524.

Hernández, H.L.H., Padilla, A.J.B., Fernández, M.A.A. \& Ángeles, O.L. 2015. Avances en requerimientos nutricionales de langostinos nativos. In: Cruz-Suárez, L.E., Risqué-Marie, D., Tapia-Salazar, M., NietoLópez, M.G., Villareal-Cavazos, D.A., GamboaDelgado, J., Rivas-Vega, M.E. \& Miranda-Baeza, A. (Eds.) Nutrición acuícola: investigación y desarrollo. Universidad Autónoma de Nuevo León, San Nicolás de los Garza, pp. 82-93.

Hoseinifar, S.H., Esteban, M.A., Cuesta, A. \& Sun, Y.Z. 2015. Prebiotics and fish immune response: a review or current knowledge and future perspectives. Reviews in Fisheries Science \& Aquaculture, 23: 315-328.

Kutty, M.N. \& Valenti, W.C. 2010. Culture of other freshwater prawn species. In: New, M.B., Valenti, W.C., Tidwell, J.H., D’Abramo, L.R. \& Kutty, M.N. (Eds.). Freshwater prawns: biology and farming. Blackwell Publishing, Oxford, pp. 502-523.

Li, P., Burr, G.S., Gatling, D.M., Hume, M.E., Patnaik, S., Castillo, F.L. \& Lawrence, A.L. 2007. Dietary supplementation of short-chain fructooligosaccharides influences gastrointestinal microbiota composition and immunity characteristic of Pacific white shrimp, Litopenaeus vannamei, cultured in a recirculating system. Journal of Nutrition, 137: 2763-2768.

Munir, M.M., Hashim, R., Chai, Y.H., Marsh, T.L. \& Nor, S.A.M. 2016. Dietary prebiotics and probiotics influence growth performance, nutrient digestibility and the expression of immune regulatory genes in snakehead (Channa striata) fingerlings. Aquaculture, 460: 59-68.

National Research Council (NRC). 2011. Nutrient requirements of fish and shrimps. National Academic Press, Washington D.C.

Peerakietkhajorn, S., Damnui, P., Wichienchot, S. \& Lheknim, V. 2019. Effects of plant oligosaccharides derived from dragon fruit on growth, reproduction and survival of freshwater crustacean Daphnia magna. Aquaculture Research, 51: 51-57.

Ring $\varnothing$, E., Olsen, R.E, Gifstad, T.Ø., Dalmo, R.A., Amlund, H., Hemre, G.-I. \& Bakke, A.M. 2010. Prebiotics in aquaculture: a review. Aquaculture Nutrition, 16: 117-136.

Rohlenová, K. \& Simková, A. 2010. Are the immune competence and the presence of metazoan parasites in cyprinid fish affected by reproductive efforts of cyprinid fish? Journal of Biomedicine and Biotechnology, 2010: 418382.

Rowley, A.F. 2016. The immune system of crustaceans. In: Radcliffe, M.J.H. (Ed.). Encyclopedia of immunobiology. Academic Press, Oxford, pp. 437-453. 
Safari, O., Shahsavani, D., Paolucci, M. \& Atash, M.M.S. 2014. Single or combined effects of fructo-and manan oligosaccharide supplements on the growth performances, nutrient digestibility, immune responses and stress resistance of juvenile narrow clawed crayfish Astacus leptodactylus leptodactylus Eschsholtz, 1823. Aquaculture, 432: 192-203.

Sang, H.M., Fotedar, R. \& Filer, K. 2011. Effects of dietary mannan oligosaccharides on the survival, growth, immunity and digestive enzyme activity of freshwater crayfish, Cherax destructor Clark (1936). Aquaculture Nutrition, 17: 629-635.

Sang, H.M., Kiev, N.T. \& Thuy, N.T.T. 2014. Effects of dietary mannan oligosaccharide on growth, survival, physiological, immunological and gut morphological conditions of black tiger prawn (Penaeus monodon Fabricius 1798). Aquaculture Nutrition, 20: 341-348.

Subramoniam, T. 2011. Mechanisms and control of vitellogensis in crustaceans. Fisheries Science, 77: 121.

Teshima, S.I., Koshio, S., Ishikawa, M., Alam, M.S. \& Hernandez, L.H.H. 2006. Protein requirements of the freshwater prawn Macrobrachium rosenbergii evaluated by the factorial method. Journal of the World Aquaculture Society, 37: 145-153.

Tyagi, A., Khushiramani, R., Karunasagar, I. \& Karunasagar, I. 2007. Antivibrio activity of recombinant lysozyme expressed from black tiger shrimp, Penaeus monodon. Aquaculture, 272: 246-253.

Received: 10 June 2020; Accepted: 28 December 2020
Van Hai, N. \& Fotedar, R. 2009. Comparison of the effects of the prebiotic (Bio-Mos ${ }^{\circledR}$ and $\beta$-1, 3-D-glucan) and the customized probiotics (Pseudomonas synxantha and $P$. aeruginosa) on the culture of juvenile western king prawns (Penaeus latisulcatus Kisjinouye, 1896). Aquaculture, 289: 310-316.

Villafuerte, M.A., Hernández, L.H.H., Fernández, M.A.A. \& Ángeles, O.L. 2016. Contribution of the knowledge of nutrient requirements of the native freshwater prawn (Macrobrachium acanthurus). Hidrobiológica, 26: $15-22$.

Yamasaki-Granados, S., Ruiz-Fragoso, M., VegaVillasante, F., Espinosa-Chaurand, L.D., CortésJacinto, E. \& Oliva-Suárez, M. 2012. Contribution to the biology of molting and growth of prawn Macrobrachium tenellum (Smith, 1871) (Decapoda: Palemonidae). Archives of Biological Sciences, 64: 651-658.

Zar, J.H. 1999. Biostatistical analysis. Prentice Hall, New Jersey.

Zhou, Z., Ding, Z. \& Huiyuan, L.V. 2007. Effects of dietary short-chain fructooligosaccharides on intestinal micro flora, survival, and growth performance of juveniles white shrimp, Litopenaeus vannamei. Journal of the World Aquaculture Society, 38: 296301. 